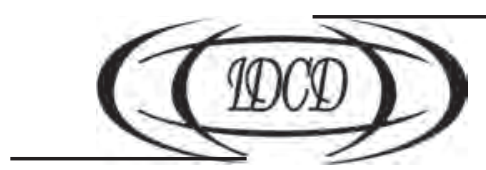

doi: $10.15407 /$ dse2016.02.089

УДК: 316.42 : [314.44 + 338.48](477)

JEL Classification: E64, I31, L83, Q26

\title{
І.С. КАЛЕНЮК
}

д-р екон. наук, проф.

Інститут демографії та соціальних досліджень

імені М.В. Птухи НАН України

01032, Україна, м. Київ, бульв. Т. Шевченка, 60

E-mail:kalenuk@ukr.net

\section{T.М. КОТЕНКО}

голов. екон.

Інститут демографії та соціальних досліджень

імені М.В. Птухи НАН України

01032, Україна, м. Київ, бульв. Т. Шевченка, 60

E-mail: kotenko_t@mail.ru

\section{СОЦІАЛЬНІ АСПЕКТИ РОЗВИТКУ РЕКРЕАЦІЇ ТА ТУРИЗМУ B УKPAÏHI}

Досліджено соціальні аспекти функціонування сфери рекреації та туризму як важливої складової людського розвитку, визначено соціальні результати рекреаційно-туристичної діяльності, узагальнено основні напрями впливу рекреації та туризму на людський розвиток і соціально-економічний розвиток держави, обгрунтовано особливості сучасного розвитку рекреаційно-туристичної діяльності в Україні. Проаналізовано динаміку споживання домогосподарствами рекреаційно-туристичних послуг, показників функціонування сфери рекреації та туризму (кількість суб'єктів, чисельність споживачів та ін.), витрати на рекреаційно-туристичні послуги в абсолютних та відносних показниках. Соціальна результативність функціонування сфери рекреації та туризму охарактеризована за допомогою аналізу доступності й охоплення оздоровчими послугами окремих категорій населення, а саме: дітей, дітей з особливими потребами, постраждалих від аварії на ЧАЕС, учасників АТО.

Доведено, що сфера рекреації та туризму здійснює як прямий вплив на соціальні параметри життя населення (поліпшення здоров'я та людського розвитку загалом), так і опосередкований вплив через поліпшення показників економічного розвитку країни: зростання ВВП, доходів населення, зайнятості тощо. Покращення всіх параметрів економічного життя населення є фундаментом підвищення його добробуту, поліпшення здоров'я та збільшення тривалості життя. Зростання доходів населення надалі стає фактором прискореного розвитку у т.ч. і сфери рекреації та туризму.

Ключові слова: соціальні аспекти функціонування сфери рекреації та туризму, соціальні результати рекреаційно-туристичної діяльності, споживання рекреаційно-туристичних послуг домогосподарствами, доступність і охоплення оздоровчими послугами соціально-вразливих категорій населення, вплив рекреації та туризму на соціальні параметри життя населення та економічний розвиток країни. 
И.С. Каленюк

д-р екон. наук, проф.

Институт демографии и социальных исследований имени М.В. Птухи НАН Украины

01032, Украина, Киев, бульв. Тараса Шевченка, 60

E-mail: kalenuk@ukr.net

\section{T.М. Котенко}

главн. экон.

Институт демографии и социальных исследований имени М.В. Птухи НАН Украины

01032, Украина, Киев, бульв. Тараса Шевченка, 60

E-mail: kotenko_t@mail.ru

\section{СОЦИАЛЬНЫЕ АСПЕКТЫ РАЗВИТИЯ РЕКРЕАЦИИ И ТУРИЗМА В УКРАИНЕ}

Исследованы социальные аспекты функционирования сферы рекреации и туризма как важной составляющей человеческого развития, определены социальные результаты рекреационно-туристической деятельности, обобщены основные направления влияния рекреации и туризма на человеческое развитие и социально-экономическое развитие государства, обоснованы особенности современного развития рекреационно-туристической деятельности в Украине. Проанализирована динамика потребления домохозяйствами рекреационно-туристических услуг, показателей функционирования сферы рекреации и туризма (количество субъектов, численность потребителей и др.), расходы на рекреационнотуристические услуги в абсолютных и относительных показателях. Социальная результативность функционирования сферы рекреации и туризма охарактеризована с помощью анализа доступности и охвата оздоровительными услугами отдельных категорий населения, а именно: детей, детей с особыми потребностями, пострадавших от аварии на ЧАЭС, участников АТО.

Доказано, что сфера рекреации и туризма осуществляет как прямое влияние на социальные параметры жмизи населения (улучшение здоровья и человеческого развития в иелом), так и опосредованное влияние через улучшение показателей экономического развития страны: рост ВВП, доходов, занятости и m. n. Улучшение всех параметров экономической жмзни населения служит фундаментом повышения его благосостояния, улучшения здоровья и увеличения продолжительности жсизни. Рост доходов населения в дальнейшем становится фактором ускоренного развития также и сферы рекреации и туризма.

Ключевые слова: социальные аспекты функционирования сферы рекреации и туризма, социальные результаты рекреационно-туристической деятельности, потребление рекреационно-туристических услуг домохозяйствами, доступность и охват оздоровительными услугами социально-уязвимых категорий населения, влияние рекреации и туризма на социальные параметры жизни населения и экономическое развитие страны.

\section{I.S. Kalenyuk}

Dr.Sc. (Economics), Prof.

Ptoukha Institute for Demography and Social Studies

of the National Academy of Sciences of Ukraine

01032, Ukraine, Kyiv-32, Taras Shevchenko Blvd., 60

E-mail:kalenuk@ukr.net

T.M. Kotenko

Chief Economist

Ptoukha Institute for Demography and Social Studies

of the National Academy of Sciences of Ukraine

01032, Ukraine, Kyiv-32, Taras Shevchenko Blvd., 60

E-mail: kotenko_t@mail.ru

\section{SOCIAL ASPECTS OF RECREATION AND TOURISM IN UKRAINE}

The social aspects of functioning recreation and tourism areas as an important component of human development are researched in the article, social outcomes of recreation and tourism activity are defined, the main ways recreation and tourism impact human development and socio-economic development of the country are sum- 
marized, features of modern development of recreational and tourism activities in Ukraine are substantiated. Dynamics of household consumption of recreational and tourist services, indicators of functioning of recreation and tourism sphere (number of subjects, number of consumers etc.), the cost of recreation and tourist services in absolute and relative indicators are analyzed. The social effectiveness of a functioning sphere of recreation and tourism are characterized by analyzing availability and coverage of health services for some population groups, namely children, children with disabilities, victims of the Chernobyl NPP disaster, participants of the anti-terrorist operation. It is proved that the sphere of recreation and tourism has a direct impact on social parameters of living of the population (improvement of health and human development in general) as well as indirect impact by improvement of country's indicators of economic development: GDP growth, income of population, employment and so on. Improving all the parameters of economic life of population is the foundation for improving its welfare, health and increased longevity. The rising incomes of population in their turn become a factor of accelerated development of the sphere of recreation and tourism also.

Key words: social aspects of functioning recreation and tourism sphere, social outcomes of recreation and tourism activity, consumption of recreation and tourism services by households, availability and coverage of health services of socially vulnerable population groups, recreation and tourism impact on social parameters of living of population and economic development of country.

Постановка проблеми. Одним із пріоритетних напрямів стратегії соціально-економічного розвитку України є формування соціально орієнтованого функціонування всіх галузей національної економіки. Важливою складовою вітчизняної економіки є сфера рекреаційної та туристичної діяльності, розвиток якої може стати вагомим чинником стабілізації та розвитку в тренді сучасних процесів соціалізації розвитку економіки в контексті забезпечення гуманітарного розвитку.

Розвинута сфера санаторно-курортного оздоровлення, відпочинку та туризму має сприяти підвищенню якості життя населення і загалом - людському розвитку. Саме тому в досягненні важливих Цілей Розвитку Тисячоліття (ЦРТ), визначених Програмою Розвитку ООН, роль рекреації та туризму є дуже вагомою. Серед визначених шести ЦРТ, що були поставлені Україною до 2015 р., три безпосередньо стосувалися сфери рекреації та туризму. Серед нових 17 цілей, визначених у вересні 2015 р., сфера рекреації та туризму може безпосередньо сприяти досягненню дев'яти.

3 іншого боку, рекреація та туризм як невід’ємна частина національної економіки відчутно впливають на їі зростання, стимулюють створення додаткових робочих місць, сприяють поповненню валютних запасів та загалом - підвищенню конкурентоспроможності економіки країни в міжнародному середовищі. Розвиток рекреаційно-туристичної сфери істотно впливає на такі сектори економіки як транспорт, торгівля, зв'язок, будівництво, сільське господарство, виробництво товарів широкого вжитку, отже $\epsilon$ одним з найперспективніших напрямів структурної перебудови економіки.

Аналіз останніх досліджень і публікацій. Дослідженню проблем рекреації та туризму в контексті функціонування рекреаційно-туристичної інфраструктури, надання туристично-рекреаційних послуг населенню, особливостей територіальної локалізації рекреаційних ресурсів, розробки і реалізації державної та регіональної політики розвитку рекреації та туризму присвятили наукові розробки відомі українські економісти, такі як 3. Герасимчук (Z. Geracimchyk), О. Гідбута (O. Hidbut), О. Грішнова (O. Grishnova), П. Гудзь (Р. Hudz), Т. Заяць (Т. Zajats), Е. Котляров (Е. Kotlyarov), В. Кравців (V. Kravtsiv), М. Крачило (M. Krachylo), Е. Лібанова (Е. Libanova), О. Любіцева (O. Lyubitseva), О. Макарова (O. Makarova), В. Новіков (V. Novikov), O. Охріменко (A. Okhrimenko), Д. Стеченко (D. Stechenko), I. Твердохлєбов (I. Tverdokhlebov), T. Ткаченко (T. Tkachenko), Н. Фоменко (N. Fomenko) та ін. [1-5]. Проблеми розвитку рекреації та туризму як видів економічної діяльності, використання природнорекреаційного потенціалу, значення і роль рекреації та туризму в соціально-еконо- 
мічному розвитку держав світу, знайшли відображення в працях багатьох зарубіжних дослідників, серед яких Р. Арєжкі (R. Arezki), Р. Чериф (R. Cherif), С. Мілн (S. Milne), I. Ательджевич (I. Ateljevic), Б. Мірбабаєв (B. Mirbabayev), M. Шагазатова (M. Shagazatova), Дж. Піотровський (J. Piotrowski), Дж. Уокер (John. Walker), А. Фрейтаг (А. Freytag) та ін.

Водночас цілий комплекс науково-практичних проблем, пов'язаних із формуванням та розвитком рекреації та туризму в соціальному вимірі, їх впливом на соціальні аспекти життя населення та розвиток економіки залишається недостатньо дослідженим у зарубіжній та вітчизняній науковій літературі. Зокрема, попри безумовний соціальний ефект функціонування цієї сфери, досі не було піднято питання про його посилення та підвищення соціальної результативності.

Метою статті $\epsilon$ дослідження соціальних аспектів функціонування сфери рекреації та туризму як важливої складової людського розвитку. Досягнення поставленої мети передбачає вирішення таких завдань: визначення соціальних результатів рекреаційнотуристичної діяльності, узагальнення основних напрямів впливу рекреації та туризму на соціально-економічний розвиток держави, обгрунтування пріоритетів підвищення соціальної результативності рекреації та туризму в Україні.

Виклад основного матеріалу. Виключно важливе значення рекреації та туризму полягає в тому, що вони відіграють і потужну економічну, і не менш вагому соціальну функцію в житті суспільства. Загальновідомою є економічна функція, що полягає у впливі на розвиток всієї національної економіки, на зайнятість, розвиток суміжних галузей тощо. В умовах ринкової економіки рекреаційно-туристична сфера забезпечує створює основи для підвищення рівня економічного розвитку територій, забезпечення зайнятості населення; розвиток суміжних галузей; впливає на доходи населення; структуру і обсяги платіжного балансу; надходження валюти від іноземного туризму до місцевих і державного бюджетів.

Рекреація та туризм є сферою для забезпечення гнучких форм зайнятості населення, що в результаті зменшує безробіття та знижує градус соціальної напруги в суспільстві. Внаслідок впливу на здоров'я знижується захворюваність, підвищується життєвий тонус тих, хто працює, що в цілому збільшує загальний фонд робочого часу. Крім того, рекреація та туризм є специфічною формою господарської діяльності, яка задовольняє наявний попит на оздоровчі і туристичні послуги. Розвиток цієї сфери впливає на інтенсивність інших галузей (легкої промисловості, сільського господарства, народних промислів тощо).

Водночас, розвиток туризму є не тільки важливим чинником економічного розвитку країни, але й соціального, культурного та духовного. Саме рекреація та туризм можуть активно сприяти ефективній реалізації концепції сталого розвитку, яка спрямована не тільки на економічне зростання, а й на соціальний прогрес, охорону навколишнього середовища та загалом - гуманістичний, етичний і культурний розвиток.

У забезпеченні людського розвитку саме рекреація та туризм дозволяють досягати соціально важливих цілей, визначених Програмою Розвитку ООН як Цілі Розвитку Тисячоліття (ЦРТ). У 2000 р. Україна приєдналася до Декларації Тисячоліття, в якій були встановлені сім цілей ЦРТ: 1) подолання бідності, 2) забезпечення якісної освіти впродовж життя, 3) забезпечення гендерної рівності, 4) зменшення дитячої смертності, 5) поліпшення здоров'я матерів, 6) обмеження поширення та скорочення масштабів ВІЛ-інфекції, СНІДу та туберкульозу, 7) сталий розвиток довкілля. Серед цих цілей безпосередньо три стосувалися сфери рекреації та туризму. Ця сфера може 
сприяти зменшенню дитячої смертності, поліпшенню здоров’я матерів та сталому розвитку довкілля. Крім того, за умови ефективної та акцентованої соціальної орієнтації, вона може впливати і на подолання бідності, і на обмеження поширення та скорочення масштабів загрозливих хвороб.

У результаті національних консультацій, широких громадських обговорень та 3 урахуванням експертної думки українських науковців в Україні створено національну аналітичну доповідь «Україна після 2015 року: Майбутнє, якого ми прагнемо». Серед нових 17 цілей, визначених у вересні 2015 р., сфера рекреації та туризму може безпосередньо сприяти досягненню вже дев'яти цілей: гарне здоров’я і благополуччя, чиста вода, санітарія, подолання бідності та голоду, гідна праця і економічне зростання, інноваційна інфраструктура, стійкі міста і населені пункти, відповідальне споживання і виробництво, боротьба зі зміною клімату, збереження екосистем суходолу та моря [6, С. 117].

Важливим соціальним результатом функціонування всієї національної економіки i, зокрема, сфери рекреації та туризму, показник очікуваної тривалості життя. Нині за показником середньої очікуваної тривалості життя при народженні (71,0 року) Україна посідає 113 місце у світі, поступаючись усім країнам з дуже високим рівнем людського розвитку, 47 з 55 країн з високим рівнем (за винятком РФ - 70,1 року), Казахстану (69,4 року), Тринідаду і Тобаго (70,4 року), Азербайджану (70,8 року), i навіть 12 з 37 країн із середнім рівнем.

Вплив рекреації та туризму на соціальні параметри життя населення є не тільки прямим. Не менш потужно ця сфера опосередковано впливає на поліпшення показників економічного розвитку країни: зростання ВВП (валового внутрішнього продукту), доходів населення, зайнятості тощо. Покращення всіх параметрів економічного життя населення є фундаментом поліпшення його здоров'я. Зростання доходів населення надалі у свою чергу стає фактором прискореного розвитку сфери рекреації. Тому особливо актуальним і цікавим є вплив рекреації та туризму на соціальні показники економічного розвитку як окремих територій, так і усієї країни.

Для депресивних, кризових територій рекреаційно-туристична діяльність може стати потужним чинником розвитку, адже вона забезпечує зайнятість населення, може певною мірою не потребувати великих інвестицій та сприяти сталому розвитку даної місцевості. На думку експертів Всесвітньої туристичної організації ООН, якщо в регіонах з активною добре диверсифікованою економікою туризм не має безумовного соціально-економічного ефекту, то саме у кризових регіонах він є фактором соціально-економічного розвитку, слугує ефективним способом забезпечення зайнятості та скорочення бідності. Свідченням цього є те, що протягом останніх років за багатьма основними показниками (економічне зростання, надходження іноземної валюти, інвестиції та кількість робочих місць) динаміка розвитку туризму була максимальною саме в кризових та слабо розвинених регіонах [7].

У кризових регіонах туризм нерідко є альтернативою іншим формам діяльності, які потребують значних інвестицій, сучасних технологій або наявності специфічних природних умов. Сучасні тенденції розвитку рекреації та туризму доводять, що для них ефективне функціонування можливе у формах екотуризму, зеленого туризму тощо, основним ресурсом яких є чисте повітря і віддаленість від міських поселень. Такі форми рекреаційно-туристичної діяльності здатні порівняно швидко забезпечити прискорення соціально-економічного розвитку.

У США в сфері туризму зайнято 9 млн осіб, що перевищує кількість працюючих у сільському господарстві, автомобільній, електронній, сталеплавильній та текстильній 
галузях промисловості разом, а їхня сукупна річна заробітна плата перевищує 500 млрд дол. У Європі майже 10 \% працюючих зайняті в сфері туризму. При цьому за темпами зростання чисельності людей, що працюють у сфері туризму, випереджає інші галузі економіки, адже витрати на створення одного робочого місця в туризмі у 20 разів менше, ніж у промисловості [8].

У сфері рекреації та туризму України у 2014 р. було зайнято 89,9 тис. осіб (1,0 \% від загальної середньооблікової кількості штатних працівників - 9 млн осіб), в т. ч. суб'єктів туристичної діяльності (ліцензійних турагентств і туроператорів) - 11,5 тис. осіб (12,8 \% від загальної кількості зайнятих у рекреаційно-туристичній сфері), у готелях та аналогічних закладах розміщування - 26,6 тис. осіб $(29,6$ \%), в санаторно-курортних і оздоровчих закладах - 51,8 тис. осіб (57,6 \%). Кількість найманих працівників (10,6 млн осіб) порівняно з 2013 р. скоротилася в усіх видах економічної діяльності, зокрема, в сфері тимчасового розміщення й організації харчування - на $8,2 \%$, мистецтва, спорту, розваг та відпочинку - найменше на 0,3 \%, і складає нині 269,9 тис. осіб (2,8 \% їх загальної кількості) [9, С. 13].

Таблиия 1. Показники соціальної результативності об’єктів та суб’єктів сфери рекреації та туризму України (2001-2014 pp.)

\begin{tabular}{|c|c|c|c|c|c|c|}
\hline Показники & 2001 & 2005 & 2011 & 2013 & 2014 & $2014 / 2013, \%$ \\
\hline $\begin{array}{l}\text { Кількість об'єктів, од.: } \\
\text { • спеціалізованих засо- } \\
\text { бів розміщення }\end{array}$ & 3304 & 3245 & 2377 & 2829 & 1928 & 68,2 \\
\hline на 10 тис. населення, од. & 0,7 & 0,7 & 0,5 & 0,6 & 0,4 & 72,1 \\
\hline $\begin{array}{l}\text { - готелів та аналогічних } \\
\text { засобів розміщення }\end{array}$ & 1258 & 1232 & 1252 & 3582 & 2644 & 73,8 \\
\hline на 10 тис. населення, од. & 0,3 & 0,3 & 0,3 & 0,8 & 0,6 & 78,1 \\
\hline $\begin{array}{l}\text { • суб'єктів туристичної } \\
\text { діяльності }\end{array}$ & 2652 & 2828 & 4793 & 5071 & 3885 & 76,6 \\
\hline на 10 тис. населення, од. & 0,6 & 0,6 & 1,1 & 1,1 & 0,9 & 81,1 \\
\hline $\begin{array}{l}\text { Кількість обслугованих / } \\
\text { оздоровлених, тис. осіб: } \\
\text { • спеціалізованими за- } \\
\text { собами розміщення }\end{array}$ & 3012 & 3267 & 2770 & 2835 & 1610 & 56,8 \\
\hline $\begin{array}{l}\text { на } 10 \text { тис. населення, } \\
\text { осіб }\end{array}$ & 622 & 696 & 607 & 624 & 375 & 60,1 \\
\hline $\begin{array}{l}\text { • готелями та аналогіч- } \\
\text { ними засобами розмі- } \\
\text { щення }\end{array}$ & 3497 & 3938 & 4657 & 5468 & 3814 & 69,8 \\
\hline $\begin{array}{l}\text { на } 10 \text { тис. населення, } \\
\text { осіб }\end{array}$ & 722 & 839 & 1021 & 1204 & 888 & 73,8 \\
\hline $\begin{array}{l}\text { • субб'єктами туристич- } \\
\text { ної діяльності }\end{array}$ & 2175 & 1826 & 2344 & 3454 & 2425 & 70,2 \\
\hline $\begin{array}{l}\text { на } 10 \text { тис. населення, } \\
\text { осіб }\end{array}$ & 449 & 386 & 514 & 760 & 565 & 74,3 \\
\hline
\end{tabular}

Джерело: за даними Держстату України. 
У масштабах держави рекреація та туризм можуть стати важелем подолання нерівномірного економічного розвитку окремих територій, стимулюючи його підвищення в економічно слаборозвинених регіонах, несприятливих для промислового та аграрного виробництва. Розвиток рекреації та туризму в цих регіонах сприятиме зайнятості населення, зменшенню міграції його до крупних міст та промислових центрів та навіть може призвести до зворотного процесу - притоку населення з інших регіонів. Тоді, як ускладнення формальностей на митниці, нестабільність фінансових показників, страйки, можуть стримувати розвиток туризму [10].

Узагальнення та аналіз інформації щодо функціонування сфери рекреації та туризму дозволяють виявити такі тенденції. Кількість спеціалізованих засобів розміщення (санаторіїв) в Україні скоротилася у 2014 р. у порівнянні з 2001 р. на 31,8 \%, готелів - на 26,2 \%, суб’єктів туристичної діяльності - на 23,4 \%. Чисельність осіб, обслугованих / оздоровлених спеціалізованими засобами розміщення, скоротилася на 43,2 \%, готелями - на 39,9 \%, суб’єктами туристичної діяльності - на 39,8 \% (табл. 1). Відповідні негативні тренди мають і відносні показники (на 10 тис. населення).

На доступність для населення рекреаційно-туристичних та соціально-культурних послуг впливають як фактори макроекономічного характеру (ВВП, видатки державного і місцевого бюджетів, доходи населення, заробітна плата), так і соціодемографічні фактори, зокрема суб'єктивні оцінки населення, які загалом визначають вибір пріоритетів у споживанні послуг. На жаль, спостерігаються значні розбіжності між бажаним і фактичним задоволенням потреб населення щодо оздоровлення, дозвілля та відпочинку. Послуги, у т. ч. рекреаційно-туристичні та соціально-культурні, надані населенню протягом 2010-2014 рр., представлені в табл. 2.

Аналіз даних табл. 2 свідчить, що в 2014 р. порівняно з 2010 р. відбулося зростання в 1,3 рази (в основному за рахунок цінового фактору) загального обсягу платних послуг, реалізованих населенню, а у розрахунку на одну особу - в 1,4 рази, обсягу рекреаційно-туристичних послуг (культури, спорту, відпочинку та розваг) - у 7,9 раза, тимчасового розміщування і організації харчування - у 3,3 раза. Також, за рівнем

Таблиия 2. Динаміка обсягів рекреаційно-туристичних та соціально-культурних послуг, реалізованих населенню, за видами економічної діяльності (включаючи ПДВ), млн грн

\begin{tabular}{|c|c|c|c|c|c|c|c|}
\hline Види діяльності & $\mathbf{2 0 1 0}$ & $\mathbf{2 0 1 1}$ & $\mathbf{2 0 1 2}$ & $\mathbf{2 0 1 3}$ & $\mathbf{2 0 1 4}$ & $\begin{array}{c}\mathbf{2 0 1 4 / 2 0 1 0 ,} \\
\mathbf{\%}\end{array}$ & $\begin{array}{c}\mathbf{2 0 1 4 / 2 0 1 3 ,} \\
\mathbf{\%}\end{array}$ \\
\hline $\begin{array}{l}\text { Всього реалізо- } \\
\text { вано населенню } \\
\text { послуг }\end{array}$ & 58439,5 & 68905,8 & 74876,1 & 80974,2 & 78837,7 & 134,9 & 97,4 \\
\hline $\begin{array}{c}\text { у розрахунку на } \\
\text { одну особу, грн }\end{array}$ & 1274 & 1531 & 1642 & 1780 & 1833 & 143,9 & 103,0 \\
\hline $\begin{array}{c}\text { у тому числі: } \\
\text { тимчасове } \\
\text { розміщування } \\
\text { і організація } \\
\text { харчування }\end{array}$ & 2738,2 & 3097,7 & 3311,6 & 3673,2 & 9067,1 & 331,1 & 246,8 \\
\hline $\begin{array}{c}\text { мистецтво, } \\
\text { спорт, розва- } \\
\text { ги та відпо- } \\
\text { чинок }\end{array}$ & 1692,5 & 2546,5 & 5067,1 & 10299,3 & 13411,2 & 792,4 & 130,2 \\
\hline
\end{tabular}

Джерело: за даними Держстату України. 
витрат на одну особу у 2014 р. було витрачено 1833 грн або приблизно 65 дол., що дозволяє віднести нашу країну до найменш розвинених у контексті створення можливостей для розвитку рекреації та туризму. В сукупності всіх реалізованих платних послуг населенню питома вага послуг культури, спорту та дозвілля зросла з 2,9 \% до 17,0 \%, послуг тимчасового розміщування і організації харчування - 3 4,7 \% до 11,5 \%.

Разом з тим, зростання обсягів реалізованих платних послуг населенню не можна відзначити як позитивну тенденцію, оскільки, по-перше, це означає обмеження доступу громадян до соціального сегменту доступних послуг, наслідком чого може стати посилення соціальної диференціації в споживанні рекреаційно-туристичних послуг. По-друге, перспективи розвитку платних послуг необхідно оцінювати з урахуванням змін у вартості послуг. Динаміка платоспроможного попиту населення на послуги конкретизується показниками споживання рекреаційно-туристичних послуг домогосподарствами. Статистичні обстеження свідчать, що у структурі домогосподарств спостерігається зростання витрат на рекреаційно-туристичні послуги в абсолютних показниках та скорочення у відносних (у відсотках до загальних споживчих витрат) (табл. 3).

Таблиця 3. Структура грошових витрат домогосподарств на відпочинок та культуру, ресторани та готелі (усі домогосподарства)

\begin{tabular}{|c|c|c|c|c|c|c|c|}
\hline Показник & 2010 & 2011 & 2012 & 2013 & 2014 & $\begin{array}{l}2014 / 2010 \\
\%,+/-\end{array}$ & $\begin{array}{l}2014 / 2013, \\
\%,+/-\end{array}$ \\
\hline \multicolumn{8}{|c|}{ Витрати на відпочинок та культуру } \\
\hline $\begin{array}{l}\text { У середньому на } \\
\text { домогосподар- } \\
\text { ство, грн }\end{array}$ & 54,48 & 65,21 & 70,37 & 76,95 & 69,76 & 128,0 & 90,7 \\
\hline $\begin{array}{l}\text { у \% до спожив- } \\
\text { чих витрат }\end{array}$ & 2,2 & 2,3 & 2,4 & 2,5 & 2,1 & $-0,1$ & $-0,4$ \\
\hline $\begin{array}{l}\text { у \% до грошо- } \\
\text { вих витрат }\end{array}$ & 2,0 & 2,1 & 2,1 & 2,2 & 1,9 & $-0,1$ & $-0,3$ \\
\hline \multicolumn{8}{|c|}{ Витрати на ресторани та готелі } \\
\hline $\begin{array}{l}\text { У середньому на } \\
\text { домогосподар- } \\
\text { ство, грн }\end{array}$ & 71,65 & 85,69 & 89,74 & 93,55 & 91,66 & 127,9 & 98,0 \\
\hline $\begin{array}{l}\text { у \% до спожив- } \\
\text { чих витрат }\end{array}$ & 2,9 & 2,5 & 2,5 & 3,0 & 2,7 & $-0,2$ & $-0,3$ \\
\hline $\begin{array}{l}\text { у \% до грошо- } \\
\text { вих витрат }\end{array}$ & 2,6 & 2,7 & 2,4 & 2,7 & 2,5 & $-0,1$ & $-0,2$ \\
\hline \multicolumn{8}{|c|}{$\begin{array}{c}3 \text { них: } \\
\text { витрати на оплату путівок на бази відпочинку тощо }\end{array}$} \\
\hline $\begin{array}{l}\text { У середньому на } \\
\text { домогосподар- } \\
\text { ство, грн }\end{array}$ & 4,73 & 8,12 & 8,11 & 5,81 & 4,32 & 91,3 & 74,4 \\
\hline $\begin{array}{l}\text { у\% до спожив- } \\
\text { чих витрат }\end{array}$ & 0,2 & 0,2 & 0,2 & 0,2 & 0,1 & $-0,1$ & $-0,1$ \\
\hline $\begin{array}{l}\text { у \% до грошо- } \\
\text { вих витрат }\end{array}$ & 0,2 & 0,3 & 0,2 & 0,2 & 0,1 & $-0,1$ & $-0,1$ \\
\hline
\end{tabular}

Джерело: за даними Держстату України. 
Соціальна результативність функціонування сфери рекреації та туризму може бути охарактеризована за допомогою аналізу доступності й охоплення оздоровчими послугами окремих категорій населення, а саме: дітей, дітей з особливими потребами, постраждалих від аварії на ЧАЕС, учасників АТО.

32014 р. суттєво погіршуються показники охоплення оздоровленням і відпочинком як загалом усіх дітей, так і дітей пільгових категорій. Влітку 2015 р. функціонувало 9743 дитячі заклади оздоровлення та відпочинку, що на 30,3 \% менше, ніж у 2014 р. та на 46,5 \% менше, ніж у 2013 р. Відповідно скоротилася кількість оздоровлених дітей до 917 тис. - на 30,2 і 53,7 \%. Питома вага оздоровлених дітей (без урахування дітей, які прибули на оздоровлення в Україну з інших країн) у загальній кількості дітей 7-16 років у 2010 р. становила $38,8 \%$, а у 2015 р. - 23,7 \% (табл. 4).

Зменшення кількості дітей шкільного віку, забезпечених оздоровленням та відпочинком у 2014 р. у порівнянні з 2013 р., зумовлено анексією Криму та проведенням антитерористичної операції, обмеженням коштів, виділених у місцевих бюджетах на оздоровлення та відпочинок дітей, реорганізацією структурних підрозділів на місцях.

Таблиця 4. Кількість дитячих закладів оздоровлення і відпочинку, які працювали влітку, і оздоровлених у них дітей, усього і пільгових категорій, 2010-2015 рр.

\begin{tabular}{|c|c|c|c|c|c|c|c|c|c|}
\hline Показник & 2010 & 2011 & 2012 & 2013 & 2014 & 2015 & $\begin{array}{c}2015 / \\
2010, \\
\%\end{array}$ & $\begin{array}{c}2015 / \\
2014, \\
\%\end{array}$ & $\begin{array}{c}20015 / \\
2013, \\
\%\end{array}$ \\
\hline $\begin{array}{l}\text { Кількість ди- } \\
\text { тячих закладів, } \\
\text { усього, од. }\end{array}$ & 17342 & 17703 & 17744 & 18549 & 13977 & 9743 & 56,2 & 69,7 & 52,5 \\
\hline $\begin{array}{l}\text { Оздоровлено ді- } \\
\text { тей, усього, тис. } \\
\text { осіб }\end{array}$ & 1718 & 1784 & 1825 & 2017 & 1346 & 917 & 58,5 & 68,1 & 45,5 \\
\hline $\begin{array}{l}\text { Питома вага } \\
\text { оздоровлених } \\
\text { дітей: } \\
\text { • у закладах } \\
\text { оздоровлення }\end{array}$ & 22,2 & 19,3 & 20,3 & 20,2 & 20,8 & 18,8 & $-0,2$ & -2 & $-1,4$ \\
\hline $\begin{array}{l}\text { • у уакладах } \\
\text { відпочинку }\end{array}$ & 77,8 & 80,7 & 79,7 & 79,8 & 79,2 & 81,2 & 0,2 & 2 & 1,4 \\
\hline $\begin{array}{l}\text { • від загаль- } \\
\text { ної кількості } \\
\text { дітей 7-16 } \\
\text { років, \% }\end{array}$ & 38,8 & 41,5 & 43,3 & 48,6 & 34,9 & 23,7 & $-15,1$ & $-11,2$ & $-24,9$ \\
\hline $\begin{array}{l}\text { Оздоровлено } \\
\text { дітей пільгових } \\
\text { категорій: } \\
\text { • усього, тис. } \\
\text { осіб }\end{array}$ & 490 & 496 & 498 & 542 & 401 & 244 & 49,8 & 60,8 & 45,0 \\
\hline $\begin{array}{l}\text { • частка у } \\
\text { загальній } \\
\text { кількості } \\
\text { оздоровлених } \\
\text { дітей, \% }\end{array}$ & 28,5 & 27,8 & 27,3 & 26,9 & 29,8 & 26,6 & $-1,9$ & $-3,2$ & $-0,3$ \\
\hline
\end{tabular}

Джерело: за даними Держстату України. 
Влітку 2014 р. оздоровлено та відпочило понад 9,3 тис. дітей внутрішньо переміщених осіб, дітей із сімей загиблих та постраждалих учасників масових акцій громадського протесту під час лютневих подій на Майдані Незалежності, дітей, батьки яких загинули, постраждали або беруть безпосередню участь у проведенні антитерористичної операції. У зв'язку із тимчасовою окупацією території АР Крим та проведенням антитерористичної операції держава втратила понад 122 дитячі заклади оздоровлення та відпочинку (у т. ч. Міжнародний дитячий центр «Артек»), а також 68 оздоровчих закладів та 533 заклади відпочинку, розміщені на території Донецької та Луганської областей.

Доволі значними є обсяги оздоровлення дітей соціально вразливих категорій, водночас, за всіма категоріями простежуються спадні тенденції за 2010-2015 рр.: чисельність оздоровлених дітей-сиріт і дітей, позбавлених батьківського піклування скоротилася з 67,6 тис. до 37,8 тис.; постраждалих у наслідок аварії на ЧАЕС з 79,3 тис. до 23,2 тис., дітей із багатодітних та малозабезпечених сімей - з 320 тис. до 169,3 тис. (12,3 \%), інвалідів - 3 22,7 тис. до 13,5 тис; (19,2 \%); [11, С. 7-8, 21].

В Україні діє Закон «Про оздоровлення та відпочинок дітей», який і регламентує надання оздоровчих послуг (діти оздоровлюються не менше 21 дня або відпочивають не менше 14 днів у стаціонарних закладах оздоровлення та відпочинку). Загалом, за бюджетні кошти всіх рівнів оздоровлюється менше 5 \% дітей. Це діти строго визначених пільгових категорій: діти-сироти та позбавлені батьківського піклування (за законом мають оздоровлюватись стовідсотково), діти з малозабезпечених та багатодітних сімей і талановиті діти.

Прискоренню темпів розвитку дитячого та підліткового оздоровлення в Україні перешкоджають: наявна матеріально-технічна база, що перебуває під юрисдикцією різних міністерств та відомств, майже зовсім не використовується для оздоровлення і відпочинку в зимовий і міжсезонний період (відбувається скорочення мережі позаміських таборів унаслідок їх перепрофілювання та браку коштів на ремонтні роботи); незадовільний контроль за ціноутворенням дитячих та молодіжних путівок, вартість яких перевищує фінансові можливості більшості молоді та їхніх батьків; відсутність гнучкої системи пільг на туристичне обслуговування дітей та молоді, в першу чергу при забезпеченні їх розміщення, харчування, транспортного та культурно-екскурсійного обслуговування.

До вразливих категорій відносяться і особи, постраждалі внаслідок Чорнобильської катастрофи. У 2014 р. забезпечувався соціальний захист громадян, які постраждали внаслідок Чорнобильської катастрофи в Україні, чисельність яких становить понад 2 млн осіб. Законом України «Про Державний бюджет України на 2014 рік» видатки на соціальний захист постраждалих громадян було передбачено у загальному обсязі 2,6 млрд гривень, у тому числі на оздоровлення та відпочинок даної категорії громадян було передбачено 370,0 млн гривень. У межах виділених коштів закуплено 63752 путівки. Водночас, дані наведені у табл. 5, свідчать про зменшення результативних показників і цієї категорії.

Починаючи з 2014 р., на жаль, розширюється коло соціально вразливих категорій населення, до яких тепер відносять і постраждалих внаслідок революційних та воєнних дій. У 2014 р. створено Державну службу України у справах ветеранів війни та учасників антитерористичної операції (постанова Кабінету Міністрів України від 11.08.2014 № 326), на яку покладено встановлення статусу учасника бойових дій учасникам антитерористичної операції, надання їм передбачених законодавством 
Таблиия 5. Динаміка кількості постраждалих внаслідок аварії на ЧАЕС, оздоровлених у спеціалізованих засобах розміщування, 2011-2014 pp.

\begin{tabular}{|c|c|c|c|c|c|c|}
\hline Показник & 2011 & 2012 & 2013 & 2014 & $\begin{array}{c}2014 / 2011 \\
\%\end{array}$ & $\begin{array}{c}2014 / 2013, \\
\%\end{array}$ \\
\hline $\begin{array}{l}\text { Кількість постражда- } \\
\text { лих внаслідок аварії на } \\
\text { ЧАЕС, оздоровлених у } \\
\text { спеціалізованих засобах } \\
\text { розміщування, всього, } \\
\text { тис. осіб }\end{array}$ & 138,9 & 116,2 & 93,6 & 73,3 & 52,7 & 78,3 \\
\hline $\begin{array}{c}\text { У тому числі: } \\
\text { санаторіях }\end{array}$ & 96,3 & 74,0 & 54,4 & 47,8 & 49,7 & 87,9 \\
\hline дитячих санаторіях & 22,0 & 19,0 & 22,7 & 18,0 & 82,1 & 79,6 \\
\hline $\begin{array}{l}\text { дитячих закладах оздо- } \\
\text { ровлення цілорічної } \\
\text { дії, дитячих центрах }\end{array}$ & 8,1 & 6,9 & 5,6 & 3,3 & 40,5 & 58,4 \\
\hline $\begin{array}{l}\text { пансіонатах з лікуван- } \\
\text { ням }\end{array}$ & 2,1 & 0,8 & 2,8 & 0,1 & 6,2 & 4,6 \\
\hline $\begin{array}{l}\text { санаторіях-профілак- } \\
\text { торіях }\end{array}$ & 5,7 & 3,2 & 3,3 & 2,6 & 45,5 & 78,4 \\
\hline $\begin{array}{l}\text { пансіонатах відпо- } \\
\text { чинку }\end{array}$ & 0,8 & 5,5 & 0,4 & 0,1 & 8,6 & 19,6 \\
\hline $\begin{array}{l}\text { базах відпочинку, } \\
\text { інших закладах відпо- } \\
\text { чинку (крім турбаз) }\end{array}$ & 3,5 & 6,7 & 4,3 & 1,2 & 34,6 & 28,3 \\
\hline
\end{tabular}

Джерело: за даними Держстату України.

соціальних гарантій, забезпечення адаптації та психологічної реабілітації, санаторно-курортного лікування, технічних та інших засобів реабілітації, соціальної та професійної адаптації, надання житла ветеранам війни.

Висновки. Україна має потужний потенціал для розвитку рекреації та туризму і посилення їхнього впливу на соціальні аспекти життя населення: відпочинку й оздоровлення, підвищення інтелектуальних можливостей і культурного рівня людини, загалом - підвищення якості життя.

Аналіз стану рекреаційно-туристичної діяльності дозволив визначити такі особливості їі сучасного розвитку:

- погіршення соціальних показників соціальної результативності функціонування сфери рекреації та туризму;

• посилення недоступності для значної частини населення цих послуг у результаті погіршення рівня життя і зменшення доходів;

- зростання структурної незбалансованості ринку рекреаційно-туристичних послуг у регіонах, втрата значної частини рекреаційно-туристичного потенціалу (Крим і Донбас);

- значна зношеність основних фондів цих підприємств; недостатність ресурсів для покращення якості послуг та інвестування.

Таким чином, на сучасному етапі рекреаційно-туристична сфера України знаходиться під впливом великої кількості негативних чинників, у першу чергу: політичної 
та економічної нестабільності, недосконалого механізму управління, погіршення соціально-економічних умов, тощо. Відповідно актуалізується питання пошуку ефективних механізмів функціонування рекреації та туризму як важливих чинників економічного і соціального розвитку національної економіки України.

Підвищення соціально-економічної результативності функціонування сфери рекреації та туризму в Україні може бути здійснено за рахунок: розробки та реалізації соціально орієнтованої державної стратегії розвитку, удосконалення державного регулювання у напрямі постійного моніторингу досягнення соціально важливих цілей, активізації механізмів державно-приватного партнерства, ефективного місцевого самоврядування; державної підтримки в їзного, внутрішнього і соціального туризму; підвищення безпеки туризму; підтримку середнього та малого бізнесу у сфері туризму; розробки механізму координування діяльності місцевих органів державної виконавчої влади та суб’єктів туристичного підприємництва.

\section{ЛІТЕРАТУРА}

1. Людський розвиток в Україні: соціальні та демографічні чинники модернізації національної економіки : [монографія] / [Лібанова Е.М., Макарова О.В., Курило І.О. та ін.] ; за ред. Е.М. Лібанової, Ін-т демографії та соціальних досліджень ім. М.В. Птухи НАН України. - К., 2012. $-320 \mathrm{c}$.

2. Людський розвиток в Україні: історичний вимір трансформації державної соціальної політики : [монографія] / за ред. Е.М. Лібанової, Ін-т демографії та соціальних досліджень ім. М.В. Птухи НАН України. - К., 2014. - 380 с.

3. Трансформація соціальної інфраструктури в контексті забезпечення гуманітарного розвитку : [монографія] / [В.М. Новіков, Н.М. Дєєва, І.С. Каленюк та ін.]. - Вінниця : ПП Балюк І.Б., 2015. $-384 \mathrm{c}$.

4. Стеченко Д.М. Наукові аспекти удосконалення організаційно-економічного механізму регулювання сфери надання рекреаційно-туристичних послуг / Д.М. Стеченко, I.В. Безуглий // Регіональна економіка. - 2013. - № 4 (70). - С. 157-166.

5. Грішнова O.A. Туризм і рекреація як чинники людського розвитку [Електронний ресурс] / О.А. Грішнова // Матеріали доповідей II науково-практичної конференції [«Інформаційні технології в управлінні туристичною та курортно-рекреаційною економікою»], (Бердянськ, 15-16 верес. 2006 р.). - Режим доступа : http://tourlib.net/statti_ukr/grishnova.htm.

6. Цілі розвитку тисячоліття. Україна: 2000-2015. Національна доповідь. - К., 2015. - 124 с.

7. Гладкевич Г.И. Неконфликтное рекреационное использование территории (зарубежный опыт для Бурятии) / Г.И. Гладкевич // Туризм и рекреация на пути устойчивого развития: отечественные и зарубежные исследования / под. ред. В.И. Кружалина, А.Ю. Александровой. - М., 2008. C. 308-322.

8. Понятие туризм и социальное влияние туризма [Электронный ресурс]. - Режим доступа : http://holm-forum.ru/turizm/opredelenie-turizma/ponyatie-turizm-i-sotscial-noe-vliyanie-turizma. html.

9. Праця України у 2014 році : стат. зб. / відп. за вип. І.В. Сеник. - К. : Консультант, 2015. - 281 с.

10. Боголюбов В.С. Экономика туризма : учеб. пособ. [3-е изд., стер.] / В.С. Боголюбов, В.П. Оровская. - М. : Академия, 2008. - 192 с.

11. Оздоровлення дітей у дитячих закладах оздоровлення і відпочинку влітку 2015 року: стат. бюлет. / [відп. за вип. О.О. Кармазіна]. - К. : Державна служба статистики України, 2015. - 58 с.

\section{REFERENCES}

1. Libanova, E.M. (Ed). (2012). Lyuds'kyy rozvytok v Ukrayini: sotsial'ni ta demohrafichni chynnyky modernizatsiyi natsional'noyi ekonomiky [Human development in Ukraine: social and demographic factors modernization of the national economy]. K. : In-t demohrafiyi ta sotsial'nykh doslidzhen' im. M.V. Ptukhy NAN Ukrayiny [in Ukrainian]. 
2. Libanova, E.M. (Ed). (2014). Lyuds'kyy rozvytok v Ukrayini: istorychnyy vymir transformazii derzhavnoi sozial'noi polityky [Human development in Ukraine: the historical dimension of the transformation of state social policy]. K. : In-t demohrafiyi ta sotsial'nykh doslidzhen' im. M.V. Ptukhy NAN Ukrayiny [in Ukrainian].

3. Novikov, V.M. (Eds.). (2015). Transformatsiia sotsial'noi infrastruktury v konteksti zabezpechennia humanitarnoho rozvytku [Transformation of social infrastructure in the context of human development]. Vinnytsia [in Ukrainian].

4. Stechenko, D.M. (2013). Naukovi aspekty udoskonalennia orhanizatsijno-ekonomichnoho mekhanizmu rehuliuvannia sfery nadannia rekreatsijno-turystychnykh posluh [Scientific aspects of improving the organizational and economic mechanism for regulation of the provision of recreation and tourism services]. Rehional'na ekonomika - Regional economy, 4(70), 157-166 [in Ukrainian].

5. Hrishnova, O.A. (2006). Turyzm i rekreatsiia iak chynnyky liuds'koho rozvytku [Tourism and recreation as factors of human development]. Proceedings from Information technology in the management of tourism and recreation economy: II naukovo-praktychna konferentsia (15-16 veresnia 2006) - Second Scientific Conference. Berdians'k, Retrieved from http://tourlib.net/statti_ukr/grishnova.htm [in Ukrainian].

6. Natsional'na dopovid', Tsili rozvytku tysiacholittia. Ukraina: 2000-2015 [Millennium Development Goals. Ukraine: 2000-2015]. (2015). Kyiv [in Ukrainian].

7. Hladkevych, H.Y. (2008). Noncontentious recreational use of the territory (foreign experience for Buryatia. Tourism and recreation in the way of sustainable development: the domestic and foreign research. Kruzhalin, V.I. \& Aleksandrova, A.Y. (Ed.). Moskow [in Russian].

8. Poniatye turyzm y sotsyal'noe vlyianye turyzma [The concept of tourism and social impact of tourism]. holm-forum.ru. Retrieved from http://holm-forum.ru/turizm/opredelenie-turizma/ponyatie-turizmi-sotscial-noe-vliyanie-turizma.html [in Russian].

9. Pratsia Ukrainy u 2014 rotsi [Labor Ukraine in 2014]. (2015). State Statistics Office of Ukraine [in Ukrainian].

10. Boholiubov, V.S. (2008). Tourism Economy. (3d ed.). Moskow : Akademyia [in Russian].

11. Ozdorovlennia ditej u dytiachykh zakladakh ozdorovlennia i vidpochynku vlitku 2015 roku [Improvement of children in institutions of rehabilitation and recreation in the summer of 2015 year]. (2015). Kyiv : State Statistics Office of Ukraine [in Ukrainian].

Стаття надійшла до редакції журналу 18 .04.2016. 